\title{
Tracer Study of the Bachelor of Science in Industrial Technology Graduates of Palompon Institute of Technology
}

\author{
Ronilo C. Montuerto, and Rex S. Mauring \\ Palompon Institute of Technology Tabango Campus, Tabango, Leyte
}

\begin{abstract}
This paper examines the employment status of the graduates related to their present occupations. This was done to assist the administrators and faculty in the enhancement of the Bachelor of Science in Industrial Technology program of Palompon Institute of Technology. The study used the descriptive type of research method with 159 graduates as respondents. The result revealed that majority or more than half $(55.34 \%)$ of the total respondents were employed and were working with jobs related to their specialization. However, there were seven percent (6.92\%) of the total respondents were unemployed as revealed in the study. In addition, over thirty-six percent (36.48) of the questionnaire were not recovered from the respondents. Most of those who were unemployed cited that the reasons of unemployment was due to family endeavors and lack of experience. Thus, curricular review should be made to ensure the provision of more skills development programs especially in technical skills which really a great help in their future career. Furthermore, the institution should establish more linkages with establishments which can provide employment to the graduates after finishing the course.
\end{abstract}

Keywords: Employment status, skills training, graduates, BS Industrial Technology program

\section{Introduction}

Tracer studies are a good source of feedback regarding the program's relevance in the current labor market (Orejana, 2010). Gaining knowledge in bachelor's degree specialization, skills and competencies development will promote productivity, efficacy and proficiency (Lalizan, 2007).

Palompon Institute of Technology - Tabango Campus was an external campus of Palompon Institute of Technology Main Campus and is located at Otabon, Poblacion, Tabango, Leyte. With its location, PIT Tabango Campus can serve through its program, the adjoining towns of Villaba, Matag-ob, San Isidro, Calubian, Leyte-leyte, including the municipalities of Biliran Province of the north. Bachelor of Science in Industrial Technology (BSIT) is one of the programs offered in Palompon Institute of Technology Tabango - Campus (PIT - TC) which comprises a vast number of enrollees in every school year. BSIT program consists of five specializations namely; Food Technology, Electrical Technology, Machine Shop Technology, Automotive Technology and Drafting Technology. Meanwhile, Drafting Technology doesn't have any enrollees from year $2013-2017$ and up to the present. The researchers were prompted to conduct the tracer study to trace the employment of the graduates if they are in their field of work in line with their area of specialization. The study aims to determine the status of the graduates in terms of their employability.

Graduate surveys and tracer studies gives information about the whereabouts of graduates, which would help to broaden perspectives among administrators, faculty and students. Such information like the employment status, filed of work, salary range, fringe benefits and reasons of unemployment of the unemployed graduates. Moreover, according to Orejana, (2010) they are a good source of feedback regarding the program's relevance in the current labor market.

However, National Economic and Development Authority (NEDA) said that the employment rate in the past two (2) years is obviously declining from July 2017, it was estimated at 94.4 percent and in July 2016, the employment rate was 94.6 percent. Based on survey, Ilocos Region (91.8\%), National Capital Region (NCR) (92.1\%), and Central Luzon (92.9\%) has the lowest employment rates. On July 2017, labor force participation 
rate (LFPR) was about at 60.6 percent. Many persons work for about less than 40 hours accounted for $51.6 \%$ of the total underemployed as of July 2017, and $54.9 \%$ as of July 2016 survey.

The number of jobless Filipinos eased while the underemployment rate fell to an over 10-year low in April, state planning agency National Economic and Development Authority (NEDA) said Friday. Citing the results of the Philippine Statistics Authority's (PSA) April 2017 Labor Force Survey, Neda said the unemployment rate declined to 5.7 percent from 6.1 percent last year.

The underemployment rate, meanwhile, hit "it's lowest in more than 10 years at 16.1 percent" in April. The rate of underemployment was "lower by 962,000 workers or 12.9 percent compared with underemployed workers recorded in April 2016," Neda said in a statement.

In addition, a lot of students go through colleges without knowing what career path they want and would end up to unemployment or underemployment. There are many careers in the field of technology graduates; they could be a food technologist, food production services, food service crew etc. For Electrical Technology graduates, include electrician, electrical installation and maintenance services and electrical engineer. For machine shop graduates, includes a machinist, technician, mechanical engineer, and parts fabrication. And for automotive technology graduates includes auto mechanics, automotive technician, and a company driver. However, there were still challenges that graduates had to face after graduation; the job mismatch and competitions among graduates. Some colleges and universities tend to produce graduates which do not match the needs and industries and graduates competes for a position in the workforce for there are graduates for example in teachers, there are lots of licensed teachers but, there are only limited slots and items for them thus, it would result to underemployment or unemployment either.

According of Prof. Adelaida C. Gines, Ph.D. of Philippine Normal University states;“...in addressing the emergent and multifaceted nature and challenges of the $21^{\text {st }}$ century, higher education stands out as one of the major keys to cope with changes. Through its indispensable functions of instruction, research, extension and production, higher education makes -up a vital and strategic part in development.

In connection to such concern, The Commission on Higher Education (CHED) was created which envisioned becoming the catalyst of the Philippine higher education system to work effectively in partnership to different stakeholders in education with a goal of building human capital towards innovation and development.

To check the effectivity of the curricular offerings and the marketability of the graduates of BSIT program, tracer study is conducted to determine what activities the graduates were involved after they graduated, and know if they land a better job that is aligned to its field of specialization and if the graduates met the needs of the industry. According to Mercado (2009) as stated in the study of Centillas, et.al (2017), the ingenuity of the Commission on Higher Education in the country to lead the conduct of graduate tracer study among selected Higher Education Institutions in order to find data that would show if HEI's are offering programs that produce graduates to meet the needs of industry and society. This job mismatch is still a problem in the industry for graduates' skills would not match the needs of the industrial world.

As a primary goal of Higher Education Institution (HEIs), PIT-TC would also like to look after and improve its services rendered to the students. It continues to look for ways and means to ensure the effectiveness of training of the school. Thus, this study was conducted to trace the employment status of the BS Industrial Technology graduates across all major of specialization to determine and establish with the necessary technical knowledge and skills so that they will determine the track they should go after graduation and to land a job which would lead to satisfaction on the job field they are in. Lalican (2007) stressed out the need to specialized skills and competencies among undergraduate students so as to promote excellent job outputs. In other words, knowledge, skills and expertise of the graduates acquired in schools would matter in their performance in their present job. 


\section{Theoretical/Conceptual Framework}

PIT-TC Aims to produce globally competitive graduates has pushed the researcher to conduct a study that would trace their employment status and profile, most especially the technology graduates of the institution previously mentioned.

The conceptual framework of the study is based on the graduates' present and past employments that would be the basis if the institutions goals were met, and if the graduates are really on their field of study.

Hence, the study focused on identify the employment profile of the technology graduates of PIT-TC from 2013-2017 in terms of their field of work, status of employment, salary, fringe benefits, and the reasons of unemployment of the unemployed graduates.

As shown in Figure 1. the employment profile of BS Industrial Technology graduates of PIT-TC and reasons of unemployment if unemployed, as the basis of their study to improve instruction, and program development.

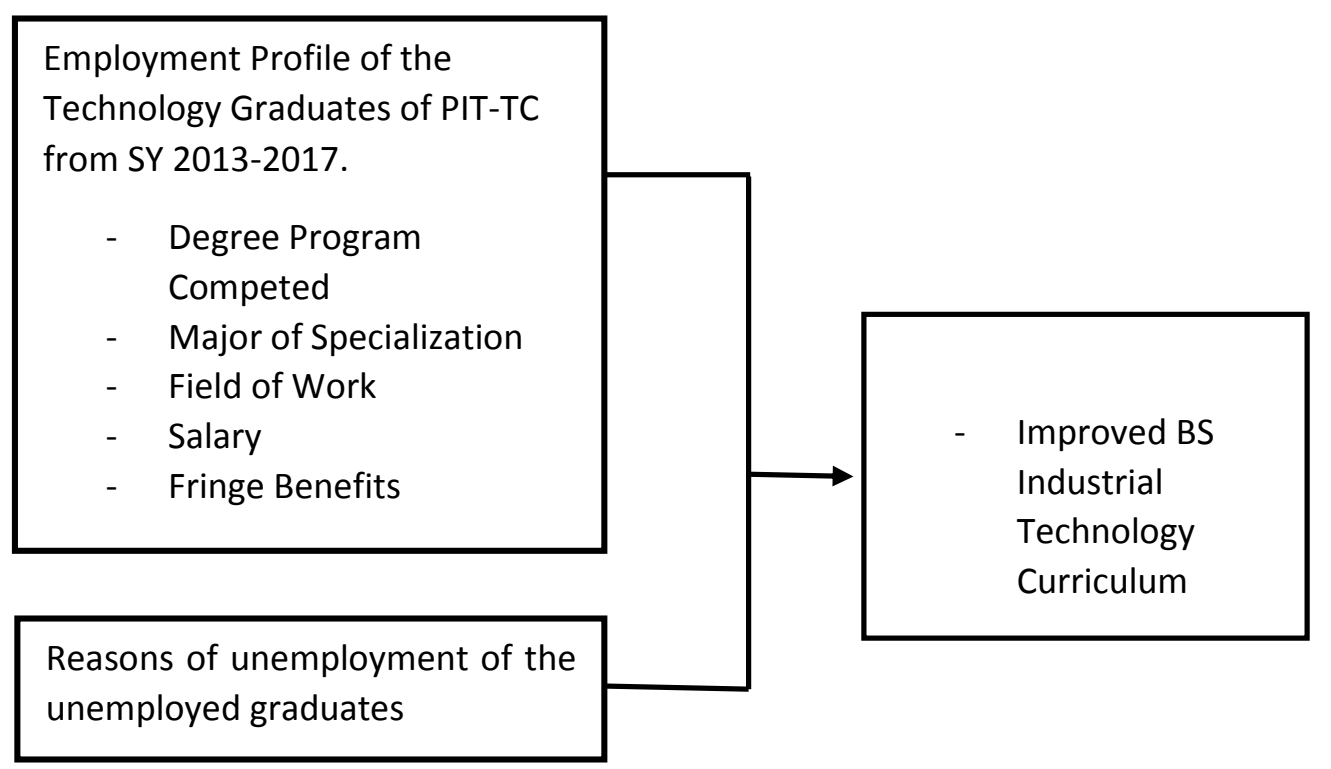

\section{OBJECTIVE OF THE STUDY}

Generally, this study aims to:

Trace the employment profile of the technology graduates of PIT Tabango Campus from 20132017

Specifically, this study aims to:

1. Identify the employment profile of the technology graduates of PIT Tabango Campus as to;

1.1 Employment: employed, unemployed or self-employed

1.2 along their field of specialization

1.3 not along their field of specialization

1.4 Salary

1.5 Fringe benefits

2. Identify reasons for unemployment of the unemployed graduates.

3. What proposal to be made for the improvement of the BSIndu. Tech Curriculum?

\section{Significance of the Study}

The researcher believes that the result of the study is significant to the following:

Students.This student would be assured of quality teaching and mentoring, thus the students would surely land a better job in the future and therefore contribute to the progress of the country. 
Teachers. The result of the study will encourage faculty to develop their teaching skills and strategies for an effective teaching-learning process. It will also give ideas in preparing and designing effective instructional materials relevant to the demands in the labor market.

Curriculum Planners. The curriculum planners are the ones who foresee the curriculum of the institute. This would also help to choose the right track on the skill to be added in the curriculum that would enhance the program offering of the institute.

School Administrators. This helps the administration to keep in track to the graduates that the institutions are producing in terms of their employability.

Future Researchers. This study will be used as instrument as reference for the future researches.

\section{Scope and Delimitations}

The study extends to the graduates who enrolled and graduated from academic year $2013-2017$ at the PIT Tabango Campus. The program being traced was BS Industrial technology across four specializations namely; Food Technology, Electrical Technology, Machine Shop Technology and Automotive Technology. The focus of the study was centered on the employment status of the graduates and on whether the specialized skills acquired from school are relevant to their present job. The study would last a period of maximum of one academic year.

\section{Methods and Procedures}

The study adopted the descriptive survey method of research in which investigates the existing conditions of the subject. This research method was designed to assist administrators, instructors and stakeholders in the enhancement of Bachelor of Science in Industrial Technology Program of Palompon Institute of Technology-Tabango Campus. This study aimed to find out the activities or jobs held by the graduates, the factors that underlying of their unemployment for those are unemployed, job satisfaction for the employed and formulate recommendations out of the results of the study to further make improvement to the program.

\section{Research Locale and Respondents}

The study consisted of 159 graduates of Palompon Institute of Technology Tabango Campus from year 2013 - 2017 taking up Bachelor of Science in Industrial Technology major in Food Technology, Electrical Technology, Machine Shop Technology and Automotive Technology. Batch 2012 - 2013 consist of 28 graduates, 2013 - 2014 has 25 graduates, $2014-2015$ has 41 graduates, 2015 - 2016 has 35 graduates and 2016 -2017 has 28 graduates a total of 159 graduates.

\section{Findings}

The descriptive survey method was utilized to determine the employment status and to determine the job aligned to its specialization of the BS Industrial Technology graduates of Palompon Institute of TechnologyTabango Campus during the academic year 2013- 2017.

As indicated in the figure 1, it was shownthat there were twenty eight (28) students who graduated in 2013, twenty five (25) in 2014, forty one in 2015, thirty five in 2016 and twenty eight in2017. It has been noticed in the graph, in Academic Year $2014-2015$ and 2014 - 2015 there is an increase of graduates. However in the succeeding years from 2015 - 2017, the number of graduates decreases. This recognized the fact that some students preferred to choose other program other than BS Industrial Technology. 
Fig. 2. Distribution of Graduates by Academic Year

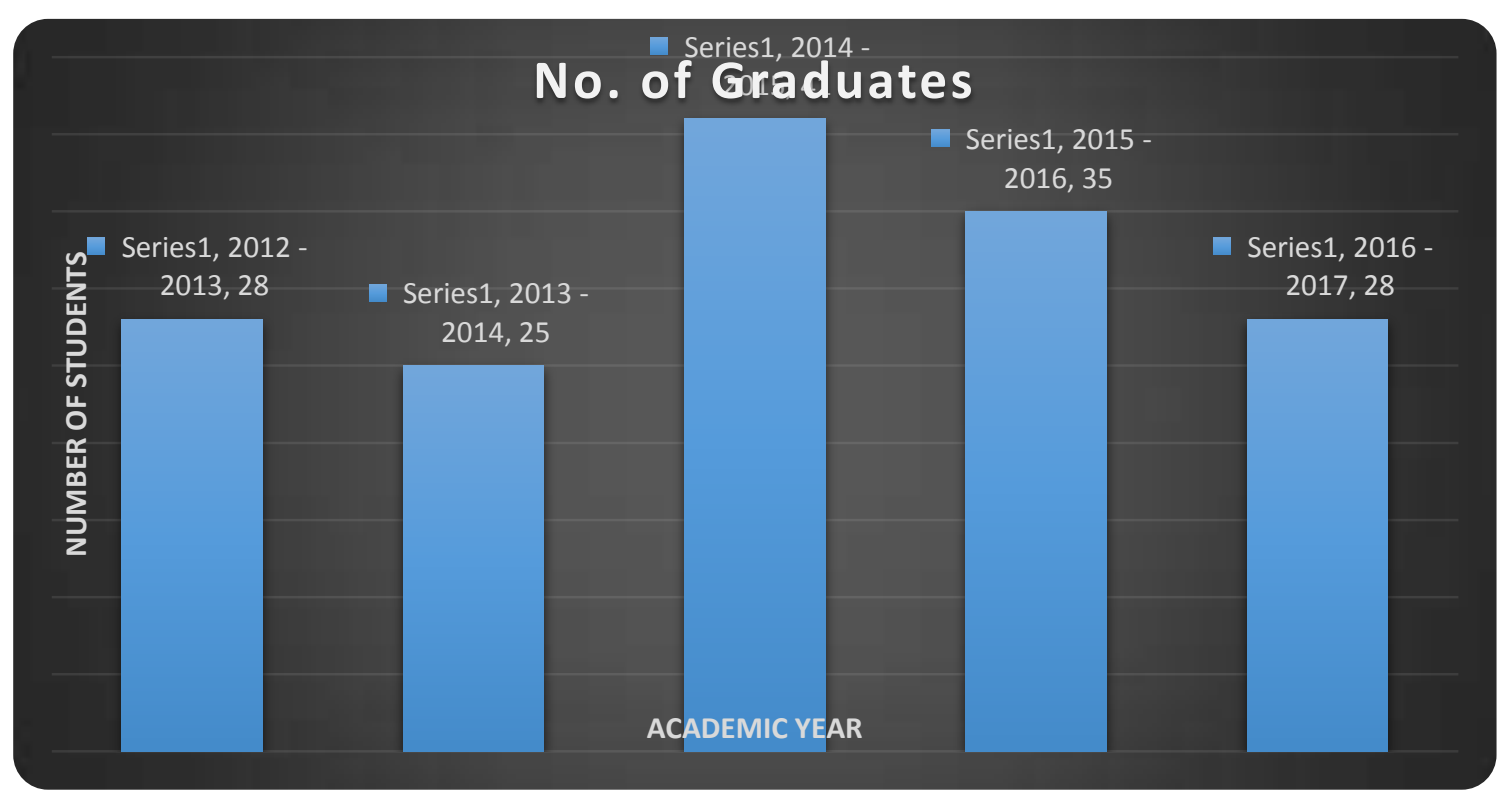

Figure 3 describe the summary of the graduates' field of specialization. As indicated in the graph there were thirty-eight (38) (24\%) students were Automotive Technology, forty-nine (49) (31\%) Electrical Technology, twenty-four (24) (15\%) Machine Shop Technology and forty-seven (47) (30\%) were Food Technology majors. The graph shown that Electrical Technology were having the largest number of graduates which composed $31 \%$ of the respondents and Machine Shop Technology had the least number of graduates which composed $15 \%$ of the respondents. This implies that most of the students prefer to take Electrical Technology as their field of specialization.

Figure 3. Distribution of Graduates by Field of Specialization

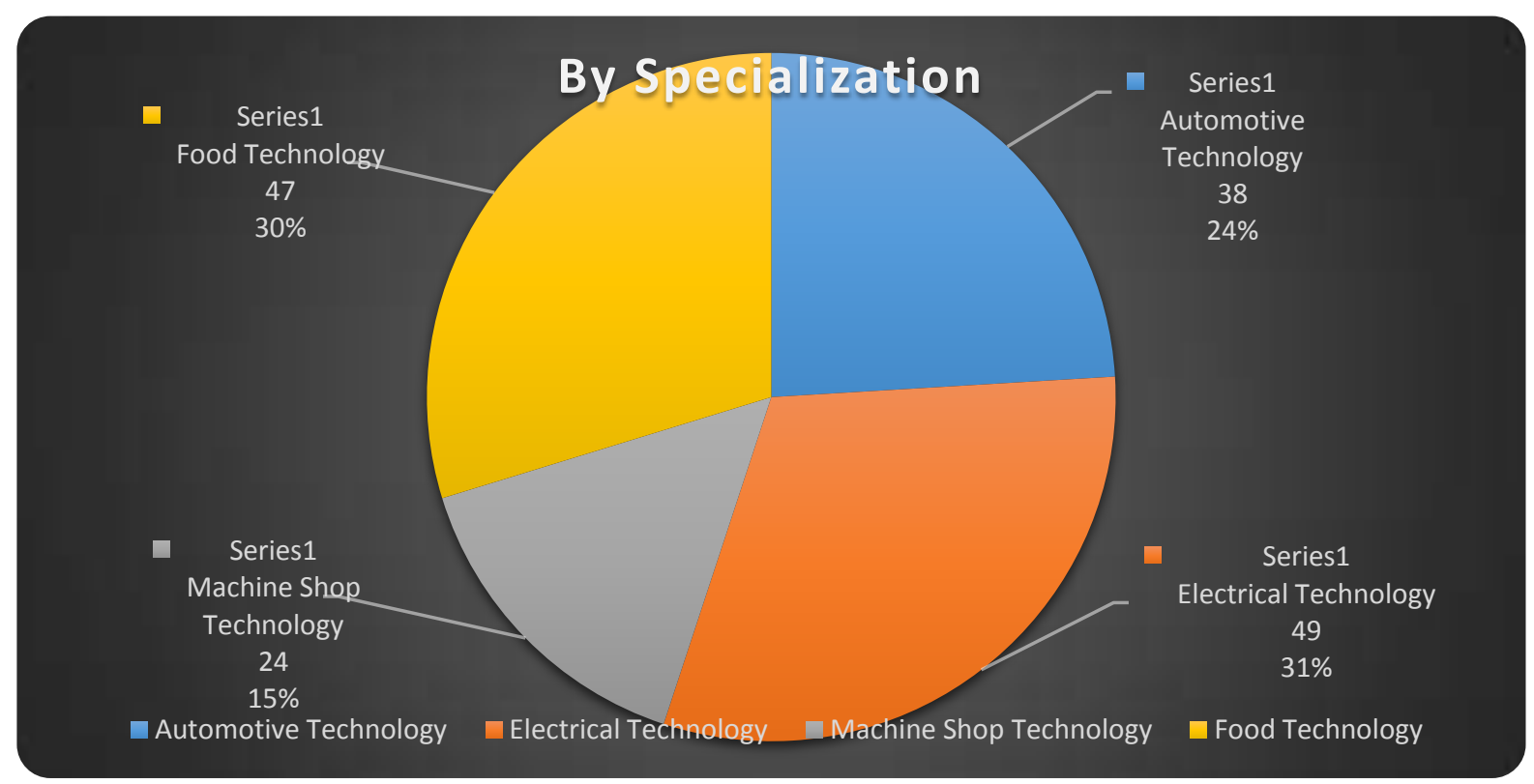


Table 1.Shows the summary of the employment status of the graduates. As indicated on the table, most of the graduates were employed which comprises the $55.34 \%$ of the respondents, $6.92 \%$ were unemployed, $1.26 \%$ were Self-employed and $36.48 \%$ of the respondents where questionnaires were not recovered. This implies that most of the graduates were able to land a job after they graduated.

Table 1. Employment Status of the Graduates

\begin{tabular}{|l|c|c|}
\hline \multicolumn{1}{|c|}{ EMPLOYMENT STATUS } & NUMBER OF GRADUATES & PERCENTAGE (\%) \\
\hline Employed & 88 & $55.34 \%$ \\
\hline Unemployed & 11 & $6.92 \%$ \\
\hline Self-Employed & 2 & $1.26 \%$ \\
\hline No response & 58 & $36.48 \%$ \\
\hline Total & $\mathbf{1 5 9}$ & $\mathbf{1 0 0 \%}$ \\
\hline
\end{tabular}

Table 2.Shows the distribution of employed and self-employed graduates who worked along and not along on their field of specialization. The table revealed that most of the employed and self-employed graduates are working aligned on their field of specialization. Out of ninety (90) employed graduates and self-employed, seventy one (71) or $78.88 \%$ worked along the field of specialization and nineteen (19) or $21.11 \%$ worked not along on their field.

Table 2. Distribution of Employed Graduates who worked along and not along to their fields of study

\begin{tabular}{|c|c|c|c|c|c|c|}
\hline \multirow[t]{2}{*}{$\begin{array}{c}\text { Field of } \\
\text { Specialization }\end{array}$} & \multicolumn{2}{|c|}{$\begin{array}{c}\text { Along the Field of } \\
\text { Specialization }\end{array}$} & \multicolumn{2}{|c|}{$\begin{array}{l}\text { Not along the field of } \\
\text { Specialization }\end{array}$} & \multicolumn{2}{|c|}{ TOTAL } \\
\hline & No. & $\%$ & No. & $\%$ & No. & $\%$ \\
\hline $\begin{array}{l}\text { Automotive } \\
\text { Technology }\end{array}$ & 18 & $20 \%$ & 6 & $6.67 \%$ & 24 & $26.67 \%$ \\
\hline $\begin{array}{l}\text { Electrical } \\
\text { Technology }\end{array}$ & 27 & $30 \%$ & 6 & $6.67 \%$ & 33 & $36.67 \%$ \\
\hline $\begin{array}{l}\text { Machine Shop } \\
\text { Technology }\end{array}$ & 12 & $13.34 \%$ & 2 & $2.22 \%$ & 14 & $15.55 \%$ \\
\hline Food Technology & 14 & $15.56 \%$ & 5 & $5.55 \%$ & 19 & $21.11 \%$ \\
\hline Total & 71 & $78.88 \%$ & 19 & $21.11 \%$ & 90 & $100 \%$ \\
\hline
\end{tabular}

Figure 4 presents the summary of the salary earned by the graduates. The graph revealed that most of the graduates earned minimum wage which comprises the $71 \%$ (64) of the employed graduates, 27\% (24) earned below minimum wage, and $2 \%$ (2) through personal earnings. The data implies that most of the graduates prefer to work for a company rather than having their own earning or business. 
Figure 4. Salary

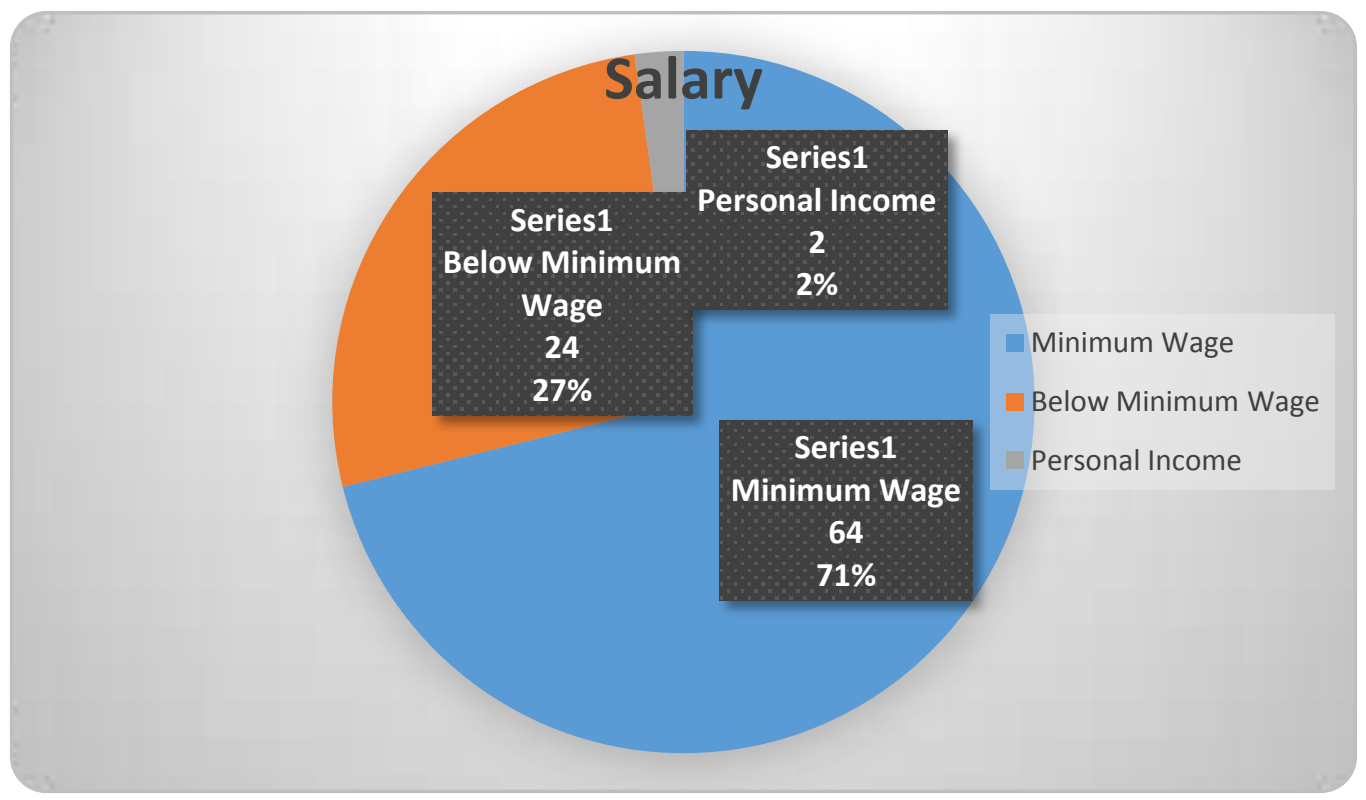

Table 3 revealed that most of the graduates who land a job enjoyed some fringe benefits given by the companies. Mostly are the minimum wage earners who enjoyed such benefits.

\section{Table 3. Other Fringe Benefits}

\begin{tabular}{|l|c|c|c|c|}
\hline \multirow{2}{*}{ Other Fringe Benefits } & \multicolumn{4}{|c|}{ No. of Graduates } \\
\cline { 2 - 5 } & \multicolumn{2}{|c|}{ YES } & \multicolumn{2}{c|}{ NO } \\
\hline & F & $\%$ & F & 14.44 \\
\hline PhilHealth, SSS, PAGIBIG & 75 & 83.33 & 13 & 26.66 \\
\hline Allowances & 64 & 71.11 & 24 & 16.66 \\
\hline Bonuses & 73 & 81.11 & 15 & \\
\hline
\end{tabular}

Table 4 revealed that most of the unemployed graduates cited that the reasons of their unemployment are family endeavors, the lack of experience and no job opportunities. However there were few cited to be because of health problems and based on the result most of the unemployed graduates are females who got married unemployed and focused on caring on their siblings.

Table 4. Reasons of unemployment of the unemployed graduates

\begin{tabular}{|l|c|c|c|c|c|c|c|c|c|c|c|c|c|}
\hline \multicolumn{1}{|c|}{ Reasons } & $\mathbf{2 0 1 2 - 2 0 1 3}$ & \multicolumn{2}{|c|}{$\mathbf{2 0 1 3 - 2 0 1 4}$} & \multicolumn{2}{|c|}{$\mathbf{2 0 1 4}-\mathbf{2 0 1 5}$} & \multicolumn{2}{|c|}{$\mathbf{2 0 1 5}-\mathbf{2 0 1 6}$} & \multicolumn{2}{|c|}{$\mathbf{2 0 1 6}-\mathbf{2 0 1 7}$} & \multicolumn{2}{c|}{ TOTAL } \\
\hline & F & $\mathbf{\%}$ & $\mathbf{F}$ & $\mathbf{\%}$ & $\mathbf{F}$ & $\mathbf{\%}$ & $\mathbf{F}$ & $\mathbf{\%}$ & $\mathbf{F}$ & $\mathbf{\%}$ & $\mathbf{f}$ & $\%$ \\
\hline Family Endeavors & 1 & 33.33 & - & - & 2 & 40.00 & 1 & 100 & - & - & 4 & 36.36 \\
\hline Health Problems & - & - & - & - & 1 & 20.00 & - & - & - & - & 1 & 9.09 \\
\hline No Job Opportunity & - & - & - & - & 1 & 20.00 & - & - & 1 & 50.00 & 2 & 18.18 \\
\hline Lack of Experience & 2 & 66.66 & - & - & 1 & 20.00 & - & - & 1 & 50.00 & 4 & 36.36 \\
\hline
\end{tabular}




\section{Conclusion}

Based on the findings presented, the researchers concluded:

1. Most of the graduates for A.Y. 2012 - 2017 were employed, only few were unemployed and selfemployed, majority of whom worked in the field related to their specialization during their college and none of them so far worked abroad, and very few engaged in self-employment.

2. Most of the graduates were able to land a job that could suffice to their daily needs and they also enjoyed some fringe benefits like insurances, allowances and bonuses.

3. There is still a mismatch on the graduates produced by the school to the needs of the industries due to the fact that the graduates still need to undergo a short training before they got hired.

4. Most of the reasons of unemployment were family endeavors and lack of experience.

\section{Recommendations}

The researchers arrived to the following recommendations:

1. Making of linkages between the College and other private establishments that can provide employment opportunities to the graduates and thus maintain higher employability rate of the graduates.

2. The review and upgrading the curricular programs to ensure the provision of more skills development programs especially in technical skills, communication skills, problem solving skills and human relations which really a great help in their future career.

3. Integration of Career Planning and Career/Vocational Guidance in the curriculum in order to educate them on how to plan their career before getting married.

4. Tracer studies such as this one should be given support by the institution for it would monitor on the activities done by the graduates and it would actually help on the further improvement of the existing curricular programs of the institute and thus improve the mode of instruction for more productive and globally competitive graduates.

\section{References}

[1] CentillasJr, C. L., Lumbay, C., \&Larisma, C. C. M. (2017). Employment Outcomes of Bachelor of Science in Information Technology Graduates in a Technological State College. International Journal of Humanities and Social Sciences, 9(2).

[2] Gines, A. C. (2014). Tracer study of PNU graduates. American International Journal of Contemporary Research, 4(3), 81-98.

[3] Guadamor, M. L., \&Eusebio, J. E. A TRACER STUDY ON THE BS CRIMINOLOGY GRADUATES IN CSU-PIAT CAMPUS.

[4] Lalican, N. M. (2007). Tracer Study of Agricultural Students. University of the Philippines, Los Banos, Laguna.

[5] Mercado, F. M. (2009). A Tracer Study of MSEUF graduates. Enverga University.

[6] National Economic and Development Authority. 